\title{
PENGARUH MODEL PEMBELAJARAN DISCOVERY LEARNING DAN MOTIVASI BELAJAR FISIKA TERHADAP KEMAMPUAN PEMECAHAN MASALAH PESERTA DIDIK DI SMA NEGERI 3 TAKALAR
}

\author{
Jumriati $^{{ }^{*}}$, Sidin Ali ${ }^{1)}$, Khaeruddin ${ }^{1)}$ \\ 1) Prodi Pendidikan Fisika, Pascasarjana, Universitas Negeri Makassar \\ e-mail: jumriati767@gmail.com
}

\begin{abstract}
Research has conducted which aims to find out: (1) how big is the problem-solving ability of students who taught through discovery learning model learning with students who taught through conventional models of State 3 Takalar dimSMA (2) as a whole, whether there are differences in the ability to solve physics problems between students taught with discovery learning and conventional learning models in SMA Negeri 3 Takalar (3) as a whole, is there a difference in the ability to solve physics problems for students who have high learning motivation and students who have low learning motivation in SMA Negeri 3 Takalar (4) whether there is an interaction between learning models with learning motivation towards students' physics problem-solving abilities at SMA Negeri 3 Takalar. This research is an experimental research using a $2 \times 2$ factorial design. Hypothesis testing performed at a significance level of $5 \%$ or $\alpha=0.05$. The results showed that: (1) The problem-solving ability of students taught through discovery learning models had higher average scores compared to students taught through conventional models at SMA Negeri 3 Takalar (2) Overall, where differences in ability physics problem solving between students taught with discovery learning and traditional learning models in SMA Negeri 3 Takalar (3) Overall, there are differences in the ability to solve physics problems for students who have high learning motivation and students who have low learning motivation in high school Negeri 3 Takalar (4) There is no interaction between the learning model and the motivation to learn physics to the students' physics problem-solving abilities at SMA Negeri 3 Takalar.
\end{abstract}

Keywords: Discovery Learning, Learning Motivation, and Physics Problem Solving Ability.

\begin{abstract}
Abstrak
Telah dilakukan penelitian yang bertujuan untuk mengetahui : (1) seberapa besarkah kemampuan pemecahan masalah peserta didik yang diajar melalui model pembelajaran discovery learning dengan peserta diidk yang diajar melalui model konvensional dimSMA Negeri 3 Takalar (2) secara keseluruhan, apakah terdapat perbedaan kemampuan pemecahan masalah fisika antara peserta didik yang diajar dengan model pembelajaran discovery learning dan konvensional di SMA Negeri 3 Takalar (3) secara keseluruhan, apakah terdapat perbedaan kemampuan pemecahan masalah fisika bagi peserta didik yang memiliki motivasi belajar tinggi dengan peserta didik yang memiliki motivasi belajar rendah di SMA Negeri 3 Takalar (4) apakah terdapat interaksi anatar model pembelajaran dengan motivasi belajar terhadap kemampuan pemecahan masalah fisika peserta didik di SMA Negeri 3 Takalar. Penelitian ini merupakan penelitian eksperimen yang menggunakan desain faktorial $2 \times 2$. Pengujian hipotesis dilakukan pada taraf signifikansi $5 \%$ atau $\alpha=0,05$. Hasil penelitian menunjukkan bahwa: (1) Kemampuan pemecahan masalah peserta didik yang diajar melalui model pembelajaran discovery learning memiliki rata-rata skor lebih tinggi dibandingkan dengan peserta didik yang diajar melalui model konvensional di SMA Negeri 3 Takalar (2) Secara keseluruhan, terdapat perbedaan kemampuan pemecahan masalah fisika antara peserta didik yang diajar dengan model pembelajaran discovery learning dan konvensional di SMA Negeri 3 Takalar (3) Secara keseluruhan, terdapat perbedaan kemampuan pemecahan masalah fisika bagi peserta didik yang memiliki motivasi belajar tinggi dengan peserta didik yang memiliki motivasi belajar rendah di SMA Negeri 3 Takalar (4) Tidak terdapat
\end{abstract}


interaksi antara model pembelajaran dan motivasi belajar fisika terhadap kemampuan pemecahan masalah fisika peserta didik di SMA Negeri 3 Takalar.

Kata Kunci: Belajar Penemuan, Motivasi Belajar dan Kemampuan Pemecahan Masalah Fisika.

\section{PENDAHULUAN}

Pembelajaran yang efektif merupakan pembelajaran yang kiranya menjadi harapan bagi setiap guru terhadap peserta didiknya. Pembelajaran efektif adalah pembelajaran yang dapat mengkondisikan peserta didik untuk mencapai tujuannya secara maksimal dengan kemampuan yang dimilikinya, akan tetapi terkadang pembelajaran tidak selalu efektif karena kemampuan yang dimiliki peserta didik belum mampu menjadi modal dalam mengatasi masalah. Terdapat lima elemen belajar yang efektif yaitu: Pertama, aptitude (kemampuan) yang bisa mempengaruhi perilaku; Kedua, perseverance (ketekunan) yang mempengaruhi motivasi; Ketiga, opportunity to learn (kesempatan untuk belajar) yang bisa mempengaruhi kreatifitas; Keempat, quality of insruction (kualitas pembelajaran) mempengaruhi kualitas pengajaran atau tingkat kejelasan pengajaran; Kelima, ability to understand (kemampuan memahami) yang bisa mempengaruhi prestasi (Manizar, 2015).

Beberapa kondisi belajar fisika yang terjadi di lapangan pada saat proses belajar mengajar berlangsung yakni (1) guru mempersiapkan peserta didik dengan baik sebelum guru memulai pembelajaran (2) guru menjelaskan materi yang akan dipelajari serta mendemonstrasikan materi sesuai dengan buku paket yang diberikan (3) guru menuntun peserta didik dalam berlatih kegiatan sesuai dengan buku (4) setelah serangkaian proses pembelajaran selesai guru memberi umpan balik kepeserta didik dengan meminta peserta didik bertanya hal-hal yang belum dipahami. Setelah proses pembelajaran selesai maka peneliti menyimpulkan bahwa model pembelajaran yang digunakan oleh guru merujuk kepada langkah-langkah pembelajaran langsung dimana pada penelitian ini pembelajaran langsung juga dikatakan metode konvensional.

Peserta didik dapat dikategorikan berhasil dalam proses belajar mengajar selama menempuh pendidikan sekolah menengah atas apabila nilai ujian nasional yang mereka peroleh memenuhi standar nilai dari sekolahnya sehingga siswa benar-benar dituntut untuk memiliki kemampuan yang menghuni untuk mencapai standar tersebut.

Beberapa karakteristik yang diperlihatkan peserta didik yakni kurangnya keingintahuan peserta didik terhadap materi pelajaran, pada saat diberi tugas mereka cenderung bekerja sama dan mengandalkan teman lainnya untuk mendapatkan jawaban karena mereka kurang percaya diri dengan jawabannya sendiri cenderung ragu untuk mengambil keputusan karena adanya rasa takut gagal. Akan tetapi tidak semua peserta didik memperlihatkan karakteristik tersebut sebagian dari mereka senang belajar, senang bila diberi tugas dan mengerjakannya, ulet dalam mengerjakan tugas serta selalu menunjukkan rasa optimis untuk berhasil.

Setelah melihat dan mempelajari beberapa karakteristik ini peneliti kemudian menyimpulkan bahwa ada perbedaan motivasi belajar yang dimiliki peserta didik. Pada saat proses pembelajaran berlangsung karakteristik di atas sering terlihat hal ini diduga dikarenakan peserta didik kurang terlibat dalam pemecahan suatu problem proses pembelajaran terjadi saru arah yang didominasi oleh guru dengan mempersiapkan peserta didik, menjelaskan dan/atau mendemonstrasikan, menuntun berlatih, memperluas latihan yang kemudian hal ini terindekasi ke dalam pembelajaran langsung. Kemudian hal ini terindekasi ke dalam pembelajaran langsung.

Model pembelajaran fisika memiliki banyak ragam mulai dari yang bersifat konvensional sampai yang modern. Setiap model pembelajaran memilki kelebihan dan kekurangan masingmasing tidak ada satu model pembelajaran yang di anggap paling cocok dan paling baik untuk 
semua jenis materi pembelajaran fisika. Salah satu model pembelajaran yang dianggap mampu mengurangi masalah yang dihadapi oleh peserta didik di SMAN 3 Takalar yakni model pembelajaran discovery learning. Model pembelajaran discovery learning memilki banyak kelebihan yang mampu meningkatkan keterampilan-keterampilan peserta didik dan menguasai konsep-konsep ide dasar agar peserta didik lebih dimudahkan dalam mengeksplor kemampuannya. Model pembelajaran yang sesuai dengan pendekatan pembelajaran saintifik adalah discovery learning (Permatasari dkk., 2018). Berdasarkan uraian di atas, maka penulis mencoba melakukan penelitian dengan judul "Pengaruh Model Pembelajaran Discovery Learning dan Motivasi Belajar Terhadap Kemampuan Pemecahan Masalah Peserta didik SMP Negeri 3 Takakar”.

\section{METODE}

\section{Jenis dan Variabel Penelitian}

Penelitian ini merupakan penelitian eksperimen dengan desain faktorial 2x2. Yang melibatkan dua kelas yaitu kelas eksperimen dan kelas kontrol. Kelas eksperimen diberi perlakuan dengan menggunakan model pembelajaran Discovery Learning. Kelas kontrol diberi perlakuan dengan menggunakan model pembelajaran konvensional. Design penelitian di gambarkan seperti tabel 1 .

Tabel 1. Rancangan Penelitian faktorial 2x2

\begin{tabular}{|c|c|c|c|}
\hline \multirow{2}{*}{ 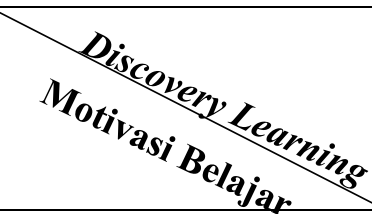 } & \multicolumn{3}{|c|}{ Model Pembelajaran } \\
\hline & $\begin{array}{c}\text { Model } \\
\text { pembelajaran } \\
\text { discovery learning } \\
\left(\mathrm{A}_{1}\right) \\
\end{array}$ & $\begin{array}{c}\text { Model } \\
\text { pembelajaran } \\
\text { konvensional } \\
\left(\mathbf{A}_{2}\right) \\
\end{array}$ & Jumlah \\
\hline $\begin{array}{l}\text { Motivasi belajar tinggi } \\
\left(\mathrm{B}_{1}\right)\end{array}$ & $\mathrm{Y}\left[\mathrm{A}_{1} \mathrm{~B}_{1}\right]$ & $\mathrm{Y}\left[\mathrm{A}_{2} \mathrm{~B}_{1}\right]$ & $\mathrm{Y}\left[\mathrm{A}_{1} \mathrm{~B}_{1}\right]+\mathrm{Y}\left[\mathrm{A}_{2} \mathrm{~B}_{1}\right]$ \\
\hline $\begin{array}{l}\text { Motivasi belajar rendah } \\
\left(\mathrm{B}_{2}\right)\end{array}$ & $\mathrm{Y}\left[\mathrm{A}_{1} \mathrm{~B}_{2}\right]$ & $\mathrm{Y}\left[\mathrm{A}_{2} \mathrm{~B}_{2}\right]$ & $\mathrm{Y}\left[\mathrm{A}_{1} \mathrm{~B}_{2}\right]+\mathrm{Y}\left[\mathrm{A}_{2} \mathrm{~B}_{2}\right]$ \\
\hline$\sum$ & $\begin{array}{c}\mathbf{Y}\left[\mathbf{A}_{1} \mathbf{B}_{1}\right]+\mathbf{Y}\left[\mathbf{A}_{1}\right. \\
\left.\mathbf{B}_{2}\right] \\
\end{array}$ & $\begin{array}{c}\mathbf{Y}\left[\mathbf{A}_{2} \mathbf{B}_{1}\right]+\mathbf{Y}\left[\mathbf{A}_{2}\right. \\
\left.\mathbf{B}_{2}\right]\end{array}$ & 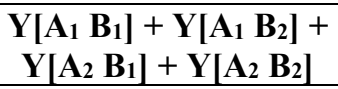 \\
\hline
\end{tabular}

Dalam penelitian ini ada beberapa variabel penelitian yang digunakan yaitu: 1) variabel bebas, variabel bebas dalam penelitian ini adalah model pembelajaran yang menerapkan model pembelajaran Discovery Learning dan konvensional, 2) variabel moderator, variabel moderator dalam penelitian ini adalah motivasi belajar fisika yang dimiliki oleh peserta didik, yang terdiri dari motivasi belajar fisika tinggi dan motivasi belajar fisika rendah, 3) variabel tak bebas, variabel tak bebas dalam penelitian ini adalah kemampuan pemecahan masalah fisika peserta didik yang ingin dicapai setelah mendapatkan suatu perlakuan.

\section{Tempat dan Waktu Penelitian}

Penelitian ini dilaksanakan di SMA Negeri 3 Takalar yang beralamat di Jln. Abdul Jalal Dg Leo No.2 Kel. Kalabbirang, Kec. Pattallassang, Kab. Takalar, Propinsi Sulawesi Selatan. Penelitian ini dilaksanakan pada semester 2 tahun ajaran 2019/2020, di mulai pada bulan Januari 2020 dan berakhir pada Maret 2020.

\section{Populasi dan Sampel}

Populasi dalam penelitian ini adalah peserta didik kelas XI SMA Negeri 3 Takalar yang terdiri dari 6 kelas yaitu kelas XI. MIA 1 sampai kelas XI. MIA 6 dengan jumlah peserta didik 198 orang. Sampel dalam penelitian ini ditentukan dengan teknik simple random sampling (Rambang sederhana). Pada teknik simple random sampling ini sebenarnya menggunakan rambang peserta didik, akan tetapi hal ini dapat mengganggu proses pembelajaran di sekolah 
tersebut. Untuk itu hanya dilakukan rambang kelas. Rambang kelas dilakukan dengan cara mengundi kelas yang akan dijadikan sampel penelitian. Dan setelah dilakukan pengundian diperoleh dua kelas sampel penelitian yaitu kelas XI IPA.2 sebagai kelas eksperimen dengan jumlah peserta didik 33 orang dan kelas XI. IPA.4 sebagai kelas kontrol dengan jumlah peserta didik 33 orang. Berdasarkan pembagian $27 \%$ kurva normal. Jumlah peserta didik secara keseluruhan pada kelas eksperimen yaitu 33 orang, sehingga 33 × 27\% diperoleh hasil 9 orang. Artinya terdapat 9 peserta didik yang di kelompok ke dalam kelompok motivasi belajar yang tinggi dan 9 peserta didik yang di kelompok ke dalam kelompok motivasi belajar yang rendah masing-masing untuk kelas eksperimen dan kelas kontrol.

\section{Desain Dan Rancangan Penelitian}

Penelitian ini menggunakan desain faktorial $2 \times 2$ yang merupakan modifikasi dari design true experiment.

\section{Teknik Pengumpulan Data}

Teknik pengumpulan data yaitu menggunakan tes dan nontes. Teknik tes pada penelitian ini berbentuk tes tertulis (soal uraian) untuk mengukur kemampuan pemecahan masalah fisika peserta didik diakhir perlakuan. Sedangkan teknik nontes dengan menggunakan kuesioner yang dilakukan sebelum proses pembelajaran berlangsung yang bertujuan untuk mengukur tingkat motivasi belajar fisika peserta didik.

\section{Instrumen Penelitian}

Kuesioner ini disusun dalam bentuk daftar pernyataan tertulis yang pilihan jawabannya telah disediakan sehingga peserta didik akan memberikan tanda centang $(\sqrt{ })$ pada salah satu pilihan jawaban tersebut. Pernyataan pada kuesioner ini terdiri atas pernyataan positif $(+)$ dan negatif (-) dan format pilihan jawaban didasarkan pada skala model Likert. Yang terdiri atas 5 (lima) pilihan yang memuat alternatif pilihan jawaban yakni: Selalu (SL); Sering (SR); Kadang-Kadang (KK); Jarang (JR); dan Tidak Pernah (TP).

\section{Teknik Analisis Data}

Analisis Uji Coba Instrumen Penelitian secara teoretis yang dilakukan dalam penelitian ini ialah menggunakan analisis Aiken's V berupa model kesepakatan antar penilai untuk validitas isi instrument (Azwar, 2014).

Analisis inferensial Sebelum melakukan analisis variansi (Anava) ini maka terlebih dahulu harus dilakukan uji prasyarat analisis yaitu uji normalitas dan uji homogenitas. Sedangkan untuk menguji hipotesis pada penelitian ini, maka dilakukan analisis variansi (anava) dua jalan dengan menghitung jumlah kuadrat (JK), derajat kebebasan (Dk), rata-rata jumlah kuadrat (RJK), F hitung, dan F tabel.

Setelah dilakukan analisis variansi (anava) dua jalan dan hasil hipotesis yang diperoleh yaitu hipotesis nol ditolak (Ho ditolak) atau hipotesis satu diterima (H1 diterima), maka dilakukan uji lanjut sebagai tindak lanjut dari analisis variansi. Uji lanjut anava ini bertujuan untuk melakukan pengecekan terhadap rerata (mean) setiap pasangan kolom, pasangan baris, dan pasangan sel. Sehingga diketahui pada bagian mana sajakah terdapat rerata (mean) yang berbeda secara signifikan maupun tidak signifikan. Uji lanjut yang digunakan pada penelitian ini adalah uji t-Dunnet.

\section{HASIL DAN PEMBAHASAN}

\section{A. Hasil}

Variabel ini diukur menggunakan instrumen soal kemampuan pemecahan masalah yang 
disebar pada peserta didik kelas XI MIA 2 dan XI MIA 4 yang berjumlah 16 butir. Berdasarkan hasil yang diperoleh dari instrumen soal kemampuan pemecahan masalah yang disebar pada 36 peserta didik, masing-masing 18 orang kelas eksperimen dan 18 kelas kontrol . Data selengkapnya dapat dilihat pada tabel 2.

Tabel 2. Rangkuman Analisis Deskriptif Skor Kemampuan Pemecahan Masalah Fisika Peserta Didik Berdasarkan Motivasi Belajar

\begin{tabular}{|c|c|c|c|}
\hline $\begin{array}{r}\text { Model Pembela } \\
\text { Motivasi Bela }\end{array}$ & $\frac{\operatorname{ran}(A)}{\operatorname{rat}(B)}$ & $\begin{array}{c}\text { Discovery } \\
\text { Learning (A) }\end{array}$ & $\begin{array}{c}\text { Konvensional } \\
\left(\mathbf{A}_{2}\right)\end{array}$ \\
\hline \multicolumn{2}{|c|}{ Skor Max yang Mungkin } & 64 & 64 \\
\hline \multicolumn{2}{|l|}{ Skor Min yang Mungkin } & 0 & 0 \\
\hline \multirow{6}{*}{ Tinggi $\left(B_{1}\right)$} & Jumlah Sampel & 9 & 9 \\
\hline & Skor Max & 62 & 60 \\
\hline & Skor Min & 54 & 50 \\
\hline & Rata-rata Skor & 57,78 & 54,89 \\
\hline & Standar deviasi & 2,54 & 2,89 \\
\hline & Varians & 6,44 & 8,36 \\
\hline \multirow{6}{*}{$\operatorname{Rendah}\left(\mathrm{B}_{2}\right)$} & Jumlah Sampel & 9 & 9 \\
\hline & Skor Max & 54 & 51 \\
\hline & Skor Min & 50 & 48 \\
\hline & Rata-rata Skor & 51,78 & 49,67 \\
\hline & Standar deviasi & 1,56 & 1,22 \\
\hline & Varians & 2,44 & 1,33 \\
\hline
\end{tabular}

Tabel 2 di atas terlihat bahwa untuk motivasi belajar fisika tinggi, skor rata-rata kemampuan pemecahan masalah fisika kelas yang diajar discovery learning yaitu 57,78 lebih tinggi dibandingkan kelas yang diajar model konvensional yaitu 54,89 dengan masing-masing standar deviasi sebesar 2,54 dan 2,89. Sedangkan untuk kemandirian belajar fisika rendah, skor rata-rata kemampuan pemecahan masalah fisika kelas yang diajar discovery learning yaitu 51,78 lebih tinggi dibandingkan kelas yang diajar model konvensional yaitu 49,67 dengan masing-masing standar deviasi sebesar 1,56 dan 1,22.

\section{Uji Hipotesis Penelitian}

Pengujian hipotesis dilakukan untuk membuktikan semua hipotesis yang diajukan. Dalam penelitian ini, hipotesis diuji dengan menggunakan analisis varian dua jalur (two way anova). Adapun hasil uji-hipotesis dengan menggunakan analisis varian dua jalur, dapat ditunjukkan seperti pada Tabel 3.

Tabel 3. Rangkuman Hasil Analisis Varians Dua Jalur (Two Way Anova)

\begin{tabular}{lcccccc}
\hline Sumber Varians & JK & db & RJK & $\mathbf{F}_{\text {hitung }}$ & $\begin{array}{c}\mathbf{F}_{\text {tabel }} \\
\mathbf{0 , 0 5}\end{array}$ & $\begin{array}{c}\text { Keputusan } \\
\text { Uji }\end{array}$ \\
\hline Antar (A) & 56,25 & 1 & 56,25 & 11,99 & 4,15 & $\mathrm{H}_{0}$ ditolak \\
Dalam (B) & 283,36 & 1 & 283,36 & 60,45 & 4,15 & $\mathrm{H}_{0}$ ditolak \\
& & & & & \\
Interaksi (AxB) & $-179,02$ & 1 & $-179,02$ & $-38,19$ & 4,15 & $\mathrm{H}_{0}$ diterima \\
Dalam Kelompok & 150,01 & 32 & 4,69 & & & \\
\hline \multicolumn{1}{c}{ Total } & 310,6 & 35 & & & & \\
\hline
\end{tabular}


Pengujian hipotesis terlebih dahulu dapat dilihat statistik skor kemampuan pemecahan masalah peserta didik berdasarkan motivasi belajar fisika yang diperlihatkan pada tabel 4 . Tabel 4. menunjukkan bahwa peserta didik yang memiliki motivasi belajar fisika tinggi yang diajar melalui model pembelajaran discovery learning lebih tinggi dibandingkan peserta didik yang diajar melalui model pembelajaran konvensional. Hal demikian sama dengan kelompok peserta didik yang memiliki motivasi belajar rendah.

Tabel 4. Statistik Skor Kemampuan Pemecahan Masalah Peserta Didik

\begin{tabular}{|c|c|c|c|}
\hline \multirow[b]{2}{*}{$\begin{array}{c}\text { Motivasi } \\
\text { Belajar } \\
\text { Fisika (B) }\end{array}$} & \multicolumn{2}{|c|}{ Model Pembelajaran (A) } & \multirow[b]{2}{*}{$\begin{array}{l}\text { Total } \\
\left(\sum \mathbf{B}\right)\end{array}$} \\
\hline & $\begin{array}{c}\text { Model } \\
\text { Pembelajaran } \\
\text { Discovery Learning } \\
\left(\mathbf{A}_{1}\right)\end{array}$ & $\begin{array}{c}\text { Model } \\
\text { Pembelajaran } \\
\text { Konvesional }\left(\mathbf{A}_{2}\right)\end{array}$ & \\
\hline \multirow{4}{*}{$\begin{array}{l}\text { Motivasi } \\
\text { Tinggi } \\
\text { (B1) }\end{array}$} & $\mathrm{n}=9$ & $\mathrm{n}=9$ & $\mathrm{n}=18$ \\
\hline & $\Sigma Y_{i}=520$ & $\Sigma Y_{i}=494$ & $\Sigma Y_{i}=1014$ \\
\hline & $\Sigma Y_{1}^{2}=30096$ & $\Sigma Y_{1}^{2}=27182$ & $\Sigma Y_{1}^{2}=57278$ \\
\hline & $\Sigma y_{1}^{2}=51,56$ & $\Sigma y_{1}^{2}=66,89$ & $\Sigma y_{1}^{2}=118,45$ \\
\hline \multirow{5}{*}{$\begin{array}{c}\text { Motivasi } \\
\text { Rendah (B2) }\end{array}$} & $\begin{array}{c}\bar{Y}=57,78 \\
\mathrm{n}=9\end{array}$ & $\begin{array}{c}\bar{Y}=54,89 \\
\mathrm{n}=9\end{array}$ & $\begin{array}{c}\bar{Y}=56,33 \\
\mathrm{n}=18\end{array}$ \\
\hline & $\Sigma Y_{i}=466$ & $\Sigma Y_{i}=447$ & $\Sigma Y_{i}=913$ \\
\hline & $\Sigma Y_{1}^{2}=24148$ & $\Sigma Y_{1}^{2}=22213$ & $\Sigma Y_{1}^{2}=833569$ \\
\hline & $\Sigma y_{1}^{2}=19,56$ & $\Sigma y_{1}^{2}=12,00$ & $\Sigma y_{1}^{2}=31,56$ \\
\hline & $\bar{Y}=51,78$ & $\bar{Y}=49,67$ & $\bar{Y}=50,72$ \\
\hline \multirow{5}{*}{ Total } & & & $\mathrm{n}=36$ \\
\hline & & & $\Sigma Y_{i}=1927$ \\
\hline & & & $\Sigma Y_{1}^{2}=103639$ \\
\hline & & & $\Sigma y_{1}^{2}=150,01$ \\
\hline & & & $\bar{Y}=53,53$ \\
\hline
\end{tabular}

1) Uji hipotesis (Antar A).

Pada tabel 3 menunjukkan bahwa $F_{\text {hitung }}=11,99>4,15=F_{\text {tabel }}$ maka $\mathrm{H}_{0}$ ditolak, dapat disimpulkan bahwa kemampuan pemecahan masalah fisika peserta didik diajar dengan menggunakan model pembelajaran discovery learning lebih tinggi dari pada peserta didik yang diajar dengan menggunakan model konvensional.

2) Uji hipotesis (Antar B).

Pada tabel 3 menunjukkan bahwa $F_{\text {hitung }}=60,45>4,15=\mathrm{F}_{\text {tabel }}$ maka $\mathrm{H}_{0}$ ditolak, dapat disimpulkan bahwa kemampuan pemecahan masalah fisika peserta didik yang memiliki motivasi belajar fisika tinggi lebih tinggi dari pada peserta didik yang memiliki motivasi belajar fisika tinggi lebih rendah.

3) Uji hipotesis (Interaksi).

Pada tabel 3 menunjukkan bahwa $F_{\text {hitung }}=-38,19<4,15=\mathrm{F}_{\text {tabel }}$ maka $\mathrm{H}_{0}$ diterima, dapat disimpulkan bahwa tidak terdapat interaksi antara model pembelajaran dengan motivasi belajar fisika terhadap kemampuan pemecahan masalah fisika peserta didik. 


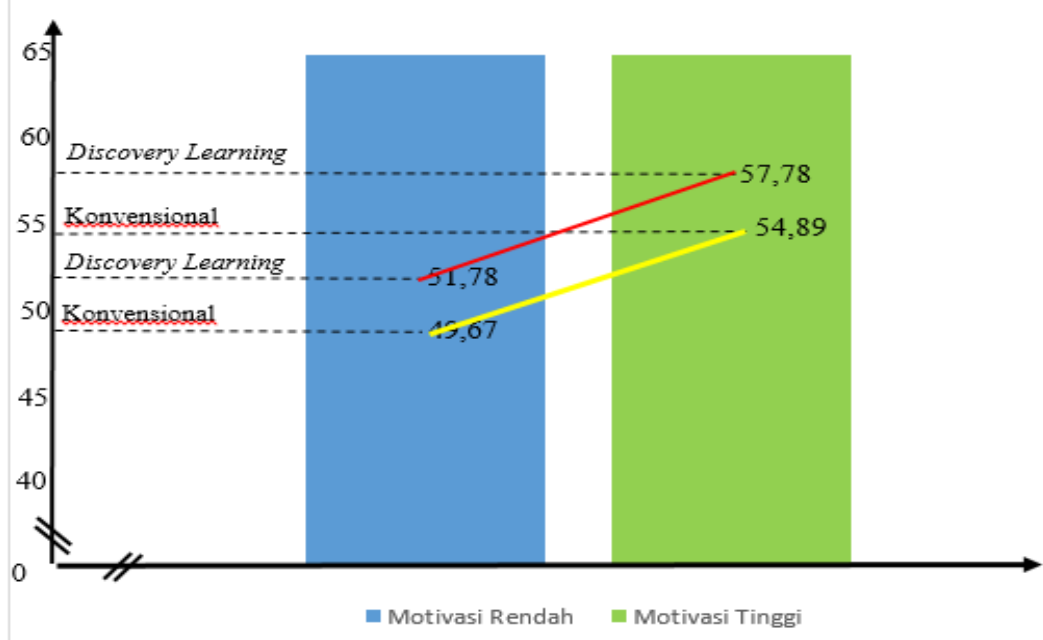

Gambar 1. Interaksi antara Model Pembelajaran dengan Motivasi Belajar

Gambar 1. menunjukkan bahwa garis merah merupakan model pembelajaran Discovery learning yang menghubungkan antara peserta didik yang bermotivasi tinggi dan rendah. Sementara untuk garis kuning, merupakan model pembelajaran konvensional yang menghubungkan peserta didik yang memiliki motivasi belajar tinggi dan rendah. Pada gambar tersebut, menujukkan kedua garis tidak berpotongan, sehingga dapat disimpulkan bahwa antara model pembelajaran dengan motivasi belajar tidak memiliki interaksi.

\section{B. Pembahasan}

Keberhasilan pendidikan tidak lepas dari beberapa faktor yang mempengaruhi. Salah satu faktor penting keberhasilan pendidikan banyak bergantung pada proses pembelajaran peserta didik di sekolah. Penggunaan model pembelajaran yang tepat dapat menumbuhkan rasa senang peserta didik terhadap pelajaran, menumbuhkan dan meningkatkan motivasi dalam menyelesaikan tugas-tugas sekolah, memberikan kemudahan bagi peserta didik untuk memahami pelajaran sehingga memungkinkan peserta didik mencapai hasil belajar yang lebih baik sebagaimana menjadi tujuan bersama.

\section{Kemampuan Pemecahan Masalah Fisika Peserta Didik Yang Diajar Melalui Model Pembelajaran Discovery Learning dan Yang Diajar Melalui Model Konvensional.}

Hasil penelitian seperti yang ditunjukkan pada tabel 4.1 menunjukka bahwa rata-rata skor kemampuan pemecahan masalah peserya didik yang diajar melalui model pembejaran discovery learning (kelas eksperimen) lebih tinggi dibandingan dengan peserta didik yang diajar melalui model konvensional (kelas kontrol) baik untuk motivasi tinggi maupun rendah. Artinya bahwa model pembelajaran discovery learning lebih unggul jika dibandingkan dengan model pembelajaran konvensional. Hasil kemampuan pemecahan masalah yang diperoleh peserta didik tidak lepas dari motivasi belajar peserta didik itu sendiri. Motivasi dapat dikatakan sebagai hal utama yang perlu untuk dimiliki peserta didik. Selain dari pada itu, model pembejaran yang digunakan kelas eksperimen yaitu discovery learning ditafsirkan jauh lebih baik dibandingkan dengan konvensional. Penelitian terdahulu memperoleh kesimpulan bahwa dengan menggunakan pembelajaran penemuan, maka peserta didik akan termotivasi mengikuti proses belajar mengajar dan pada akhirnya hasil kemampuan pemecahan masalah meningkat . Secara teori (Dewi dkk., 2015), Piaget mengatakan semestinya siswa SMA kelas XII dengan rentangan umur antara 14 sampai 16 tahun kemampuan berpikir formalnya sudah berada pada 
kualifikasi tinggi, jika kelima faktor penentu perkembangan intelektual siswa, yaitu (1) kedewasaan, (2) pengalaman fisik, (3) pengalaman logiko matematik, (4) transmisi sosial, dan (5) pengaturan-diri berinteraksi dan berkontribusi secara optimal dalam pengembangan intelektual anak. Tampaknya teori Piaget tentang perkembangan intelektual anak bahwa anak yang telah berusia 11 tahun ke atas sudah mencapai operasi formal sesuai dengan kondisi anak kelas XI di SMA Negeri 3 Takalar (Sadia, 2007).

\section{Secara Keseluruhan, Perbedaan Kemampuan Pemecahan Masalah Peserta Didik Kelas Eksperimen dan Kelas Kontrol.}

Hasil penelitian ini menunjukkan bahwa secara keseluruhan terdapat perbedaan kemampuan pemecahan masalah fisika antara peserta didik yang diajar dengan model pembelajaran discovery learning dan peserta didik yang mengikuti pembelajaran dengan metode konvensional. Hal ini dapat dilihat pada analisis varians dua jalur (two way anova) yang menunjukkan nilai $F_{\text {hitung }}>F_{\text {tabel }}$ yaitu $11,99>4,15$ pada taraf signifikan $\alpha=0,05$. Dengan hasil ini maka hipotesis $\mathrm{H}_{\mathrm{o}}$ ditolak.

Proses pembelajaran di kelas eksperimen menggunakan model discovery learning yang tentu masuk ke dalam salah satu model pembelajaran saintifik menekankan pembelajaran yang berpusat kepada peserta didik. Pembelajaran discovery learning memiliki sintak atau langkahlangkah pembelajaran yang mampu membuat peserta didik untuk lebih mengeksplor kemampuan mereka dalam bernalar serta menemukan atau menyelesaikan sebuah problem yang telah disajikan oleh pendidik. Langkah-langkah model pembelaran discovery learning yang digunakan pada kelas eksperimen yakni:

\section{1) Stimulation (stimulasi/pemberian rangsangan)}

Pada tahap ini peserta didik dihadapkan pada suatu pemikiran yang menimbulkan tanda tanya, kemudian dilanjutkan untuk tidak memberi generalisasi, agar timbul keinginan untuk menyelidiki sendiri. Disamping itu guru dapat memulai kegiatan proses belajar mengajar dengan mengajukan pertanyaan, anjuran membaca buku, dan aktivitas belajar lainnya yang mengarah pada persiapan pemecahan masalah peserta didik. Stimulus biasanya sudah tertera di dalam lembar kerja peserta didik (LKPD), dibagi setiap kelompok. Setelah LKPD dibagikan peserta didik terlebih dahulu diminta untuk membaca dengan cermat agar memudahkan dalam mengidentifikasi masalah.

2) Problem statement (pernyataan/identifikasi masalah)

Setelah langkah stimulasi dilaksanakan, langkah selanjutnya adalah guru memberi kesempatan kepada peserta didik untuk mengidentifikasi sebanyak mungkin masalah-masalah yang dirasa relevan dengan bahan pelajaran serta berkaitan dengan stimulus sebelumnya, kemudian salah satu permasalahan yang ada dipilih dan dirumuskan dalam bentuk hipotesis (jawaban sementara atas pertanyaan masalah) yang dituliskan ke dalam LKPD yang sudah dibagikan. Pada tahap ini peserta didik lebih dituntut untuk bekerja sama dengan teman kelompoknya dan mengeluarkan pendapat mereka masing-masing mengenai masalah serta solusi-solusi yang kiranya mampu menjawab permasalahan.

3) Data collection (pengumpulan data)

Ketika proses eksplorasi berlangsung tak lupa guru juga memberi kesempatan kepada para peserta didik untuk mengumpulkan informasi sebanyak mungkin yang relevan guna membuktikan benar atau tidaknya hipotesis yang telah dibuat sebelumnya. Pada tahap ini semua anggota kelompok masing-masing mencari data yang kiranya bisa dijadikan sebagai referensi untuk menjawab pertanyaan atau membuktikan benar tidaknya hipotesis yang dibuat. Dengan demikian peserta didik diberi kesempatan untuk mengumpulkan (collection) berbagai informasi-informasi yang relevan, dengan cara membaca literatur-literatur yang berhubungan. 


\section{4) Data processing (pengolahan data)}

Semua informasi yang diperoleh baik hasil bacaan maupun lainnya, diolah, diacak, diklasifikasikan, ditabulasi, bahkan bila perlu dihitung dengan cara tertentu serta ditafsirkan pada tingkat kepercayaan tertentu. Pada tahap inilah peserta didik melakukan sebuah percobaan baik percobaan secara real dengan menggunakan alat laboratorium secara langsung maupun menggunakan aplikasi hal ini tergantung dari kebutuhan serta materi yang diajarkan. Sebelum percobaan dimulai mereka membagi tugas sehingga setiap anggota kelompok memiliki tugas dan tanggung jawab masing-masing disetiap percobaan dengan tujuan memudahkan pada tahap pembuktian atau penyelesaian permasalahan serta mengantisipasi adanya data yang terlewatkan pada saat percobaan berlangsung.

\section{5) Verification (pembuktian)}

Pada tahap ini peserta didik melakukan pemeriksaan secara cermat untuk membuktikan benar atau tidaknya hipotesis yang ditetapkan sebelumnya dengan temuan alternatif, yang kemudian dihubungkan dengan data hasil percobaan. Verification menurut Bruner, bertujuan agar proses belajar akan berjalan dengan baik dan kreatif jika guru memberikan kesempatan kepada peserta didik untuk menemukan suatu konsep, teori, aturan atau pemahaman melalui contoh-contoh yang mereka jumpai dalam kehidupannya. Jadi, dari hasil percobaan tersebut kemudian di hubungkan dengan teori yang ada sehingga tercipta teori baru dalam menyelesaiakan masalah yang ada.

6) Generalization (menarik kesimpulan/generalisasi)

Pada tahap ini peserta didik berunding dengan teman kelompoknya untuk menarik sebuah kesimpulan yang akan menjawab hipotesis karena tahap generalisasi/menarik kesimpulan adalah proses menarik sebuah kesimpulan yang dapat dijadikan prinsip umum dan berlaku untuk semua kejadian atau masalah yang sama, dengan memperhatikan verifikasi). Kemudian setelah peserta didik menarik kesimpulan peserta didik harus memperhatikan proses generalisasi yang menekankan pentingnya penguasaan pelajaran atas makna dan kaidah atau prinsip-prinsip yang luas yang mendasari pengalaman seseorang, serta pentingnya proses pengaturan dan generalisasi dari pengalaman-pengalaman itu. Peserta didik juga tidak lupa untuk mempresentasikan hasil temuannya ke depan teman-teman lainnya guna mendapatkan respon yang kemudian setelah semua kelompok melakukan presentase maka guru meluruskan materi sesuai dengan yang seharusnya.

Salah satu langkah pembelajaran yang membuat peserta didik mampu menyelesaikan masalah ialah diberikannya kesempatan untuk menemukan dan mengolah data secara mandiri dalam menemukan solusi yang paling tepat terhadap masalah yang tercipta, tentu bukan hal mudah bagi peserta didik dalam menentukan sebuah solusi yang tepat akan tetapi dengan mengikuti langkah-langkah pembelajaran secara benar serta serius maka hasil yang diperoleh juga akan sesuai dengan harapan.

Dilihat dari rata-rata skor kemampuan pemecahan masalah fisika, kelompok peserta didik yang mengikuti pembelajaran dengan model discovery learning memiliki nilai rata-rata yang lebih besar yaitu sebesar 54,78 dibandingkan kelompok peserta didik yang mengikuti pembelajaran dengan metode konvensional yaitu sebesar 52,28. Hasil ini menunjukkan bahwa kelompok peserta didik yang mengikuti pembelajaran dengan model discovery_learning memiliki kemampuan pemecahan masalah fisika yang lebih baik dari pada kelompok peserta didik yang mengikuti pembelajaran dengan model konvensional.

Menurut penelitian terdahulu model pembelajaran discovery learning memiliki kelebihan yang baik bagi peserta didik yakni (1) membantu peserta didik untuk memperbaiki dan meningkatkan keterampilan-keterampilan dan proses-proses kognitif, (2) meningkatkan kemampuan peserta didik untuk memecahkan masalah, (3) peserta didik akan mengerti konsepkonsep dasar dan ide-ide, (4) mengembangkan potensi intelektual dan (5) mempertahankan memori (Suprihatiningrum, 2017). Jadi, dapat dikatakan bahwa kemampuan pemecahan 
masalah peserta didik yang menggunakan model pembelajaran discovery learning lebih tinggi dari pada peserta didik yang diajarkan melalui metode konvesional karena dalam discovery learning peserta didik aktif dalam mencari dan menemukan data-data yang diperlukan dalam penyelesaikan masalah sama halnya yang telah dikemukakan oleh Fitri dan Derlina bahwa peserta didik yang diajar menggunakan model pembelajaran penemuan cenderung lebih aktif dan perannya dalam belajar sangat dominan (Fitri dan Derliana, 2015).

Sedangkan pada kelas kontrol dilakukan proses pembelajaran dengan menggunakn metode konvensional yaitu model pembejaran yang turun temurun digunakan oleh guru di sekolah. Langkah-langkah pembelajaran konvensional yakni:

1) Mempersiapkan peserta didik

Menyampaikan kompetensi dan tujuan pembelajaran serta mempersiapkan peserta didik. Guru menjelaskan kompetensi dan tujuan pembelajaran, informasi latar belakang pelajaran, pentingnya pelajaran, mempersiapkan peserta didik untuk belajar.

2) Menjelaskan dan/atau mendemonstrasikan

Guru mendemonstrasikan pengetahuan dan keterampilan yang benar atau menyampaikan informasi tahap demi tahap. Hal demikian berbeda dengan kelas eksperimen yang menggunakan model discovery learning peserta didik dituntut untuk menentukan menentukan hipotesis percobaan terlebih dahulu sehingga rasa penasaran akan percobaan selalu ada yang membuat mereka lebih semangat melakukan percobaan.

3) Menuntun berlatih

Guru merencanakan dan memberikan bimbingan pelatihan awal. Sedangkan pada kelas eksperimen peserta didik dibebaskan untuk mengeksplor kemampuan mereka. Mereka yang berencana mereka pula yang mengerjakan hingga mencapai sebuah hasil yang diharapkan dan hal ini lebih berkesan terhadap peserta didik.

4) Memberikan umpan balik

Mengecek apakah peserta didik telah berhasil melakukan tugas dengan baik, memberikan umpan balik. Peserta didik di beri kesempatan untuk menanyakan materi-materi yang belum diketahui pada saat melakukan percobaan. Kebalikan dari discovery learning yang di awali dari rasa penasaran peserta didik yang kemudian melakukan percobaan dan mendapat jawaban.

5) Memperluas latihan.

Guru mempersiapkan kesempatan melakukan pelatihan lanjutan, dengan pelatiha khusus pada penerapan kepada situasi lebih komplek dalam kehidupan sehari-hari. Pembelajaran secara konvensional peran peserta didik masih kurang serta masih didominasi oleh pendidik. Kurangnya partisipasi peserta didik membuat pembelajaran kurang membekas diingatan bahkan bisa berlalu begitu saja sehingga tidak salah jika mereka masih kurang mampu dalam menyelesaikan permasalahan yang di berikan. Jadi dapat dikatakan bahwa pada kelas eksperimen tingkat kemampuan pemecahan masalahnya lebih tinggi dibandingkan dengan kelas kontrol yang dikarenakan di kelas eksperimen peserta didik lebih berpartisipasi di bandingkan dengan pada kelas kontrol.

Pernyataan di atas sama halnya yang telah dikemukakan oleh Handayani Elsa dan Simamora Pintor bahwa Model discovery learning dapat membuat peserta didik aktif untuk menemukan sendiri, menyelidiki sendiri, dan memecahkan sendiri masalah yang diperoleh melalui praktikum dan referensi yang digunakan sehingga kemampuan pemecahan masalah kelas eksperimen lebih tinggi dari pada kelas control (Handayani, 2019). Hal ini juga dikemukan oleh hasil penelitian Hariyanto bahwa model discovery learning memberikan pengaruh yang signifikan terhadap hasil belajar peserta didik dan kemampuan pemecahan masalah peserta didik karena dalam model ini terdapat aktivitas peserta didik secara langsung, kegiatannya berpusat pada peserta didik sehingga lebih paham pada konsep fisika yang sedang dipelajari, pada akhirnya mampu memecahkan masalah fisika dengan baik (Haryanto, 2015). 


\section{Secara Keseluruhan, Perbedaan Kemampuan Pemecahan Masalah Fisika Bagi Peserta Didik Yang Memiliki Motivasi Belajar Tinggi Dengan Peserta Didik Yang Memiliki Motivasi Belajar Rendah}

Hasil penelitian ini menunjukkan bahwa kemampuan pemecahan masalah fisika bagi peserta didik yang memiliki motivasi belajar tinggi lebih tinggi dibandingkan peserta didik yang memiliki motivasi belajar fisika rendah. Hal ini dapat dilihat pada tabel 4.2 analisis hasil varians dua arah (two way anova). Berdasarkan hasil analisis, diperoleh nilai $\mathrm{F}_{\text {hitung }}$ yang lebih besar dari nilai $F_{\text {tabel }}$ yaitu $F_{\text {hitung }}=60,45>F_{\text {tabel }}=4$, 15, sehingga secara statistik dapat disimpulkan bahwa $\mathrm{H}_{\mathrm{o}}$ ditolak. Jadi, secara keseluruhan kemampuan pemecahan masalah peserta didik yang memiliki motivasi belajar fisika tinggi lebih tinggi dibandingkan peserta didik yang memiliki motivasi belajar fisika rendah.

Seperti yang dikemukan oleh penelitian terdahulu bahwa ada lima elemen belajar yang efektif yaitu : Pertama, aptitude (kemampuan) yang bisa mempengaruhi perilaku; Kedua, perseverance (ketekunan) yang mempengaruhi motivasi; Ketiga, opportunity to learn (kesempatan untuk belajar) yang bisa mempengaruhi kreatifitas; Keempat, quality of insruction (kualitas pembelajaran) mempengaruhi kualitas pengajaran atau tingkat kejelasan pengajaran; Kelima, ability to understand (kemampuan memahami) yang bisa mempengaruhi prestasi.

\section{Interaksi Antara Model Pembelajaran Dengan Motivasi Belajar Terhadap Kemampuan Pemecahan Masalah Peserta Didik}

Hasil penelitian ini menunjukkan bahwa tidak terdapat interaksi antara model pembelajaran (discovery learning dan konvensional) dan motivasi belajar terhadap pencapaian kemampuan pemecahan masalah fisika pada peserta didik kelas XI MIA SMAN 3 Takalar. Berdasarkan hasil analisis uji hipotesis, diperoleh nilai $F_{\text {hitung }}$ yang lebih kecil daripada nilai $F_{\text {tabel }}$ yaitu $-38,19<4,17$ pada taraf signifikan $\alpha=0,05$ sehingga secara statistik $\mathrm{H}_{\mathrm{o}}$ diterima dan $\mathrm{H}_{\mathrm{a}}$ ditolak. Hal ini menyatakan bahwa antara model pembelajaran (discovery learning dan konvensional) dengan motivasi belajar (tinggi dan rendah) tidak memiliki interaksi dalam pencapaian kemampuan pemecahan masalah fisika pada peserta didik kelas XI MIA SMA Negeri 3 Takalar. Hal demikian juga di peroleh Putri pada penelitiannya bahwa tidak terdapat hubungan langsung yang signifikan antara motivasi belajar dengan kemampuan pemecahan masalah dengan nilai koefisien sebesar $-0,049$.

\section{KESIMPULAN}

Berdasarkan hasil analisis kemampuan komunikasi matematis siswa SMP di Kota Pekanbaru dalam menyelesaikan soal-soal bangun ruang sisi lengkung dapat diambil kesimpulan bahwa dalam kemampuan komunikasi matematis siswa yang berkemampuan tinggi sudah mampu mencapai indikator dalam mendefenisikan dan merancang kembali ide matematis menghubungkan benda nyata, gambar, diagram, menggunakan istilah-istilah matematika untuk menyelesaikan masalah. Faktor hambatan yang dimiliki siswa yang berkemampuan tinggi adalah faktor membaca dan menulis. Kelompok yang berkemampuan sedang sudah mampu mencapai indikator dalam mendefenisikan dan merancang kembali ideide matematis, menghubungkan benda nyata, gambar dan diagram untuk menyelesaikan masalah, faktor hambatan yang dimiliki siswa yang berkemampuan sedang adalah faktor membaca, menulis dan pemahaman materi bangun ruang sisi lengkung. Kelompok yang berkemampuan rendah mampu mencapai mendefenisikan dan merancang kembali ide-ide matematis untuk menyelesaikan masalah, Faktor hambatan yang dimiliki siswa yang berkemampuan sedang adalah faktor pengetahuan prasyarat, membaca, menulis dan pemahaman materi bangun ruang sisi lengkung. 


\section{DAFTAR PUSTAKA}

Azwar. 2014. Reliabilitas dan Validitas, Edisi 4. Yogyakarta: Pustaka Pelajar.

Dewi, N. M. S. N., Jampel I N \& Sudarma I. K. 2015. Pengaruh model discovery learning terhadap motivasi belajar IPA siswa kelas IV gugus I Kecamatan Jembrana. ejurnal mimbar PGSD Universitas Pendidikan Ganesha vol. 3 (1):1 - 10.

Elly Manizar. 2015. Peran guru sebagai motivator dalam belajar. vol. 1 no.2, 172.

Fitri. M,. dan Derlina. 2015. Pengaruh model pembelajaran penemuan terhadap hasil belajar siswa pada materi pokok suhu dan Kalor. Jurnal Inpafi. Vol 3(2): 89-96.

Handayani, E. \& Pintor Simamora. 2019. Pengaruh model discovery learning berbantuan media phet terhadap kemampuan pemecahan masalah tingkat SMA pada materi pokok fluida dinamis. Jurnal Inovasi Pembelajaran Fisika (INPAFI). vol 7 (3). Available online http://jurnal.unimed.ac.id/2012/index.php/ inpafi.

Haryanto, Agus. 2015. Efektifitas model problem based learning berbantuan mind map terhadap kemampuan pemecahan masalah. jurnal pendidikan dan kebudayaan. vol 21, nomor 3.

Permatasari, I., Feriansyah Sesunan, Ismu Wahyudi. Perbandingan Hasil Belajar Siswa Antara Model Guided Inquiry Dan Discovery Learning. 2018. Journal Of Komodo Science Education, Vol. 01 No. 01, 53.

Sadia I Wayan. 2007. Pengembangan kemampuan berpikir formal siswa SMA melalui penerapan model pembelajaran "problem based learning" dan "cycle learning" dalam pembelajaran fisika. Jurnal Pendidikan dan Pengajaran UNDIKSHA, No. 1.

Suprihatiningrum, J. 2017. Strategi pembelajaran teori dan aplikasi (II). Yogyakarta: ArRuzz Media. 